\title{
Causes of Formation Damage and Guidelines for Remadial Treatment for Western Sirte Bain Libyan Carbonate Oil Reservoirs
}

\author{
Mohamed S. Nasr ${ }^{1}$, Abdulrrazag Y. Zekri ${ }^{2}$, and Amer A. Aborig ${ }^{3}$
}

\begin{abstract}
Formation damage is the main cause of decreasing the production in many oil wells because of reducing the inflow from the reservoir to the well bore which is caused by lowering the permeability in the well bore region. The reduction in the permeability is caused by many factors among which organic or inorganic scale precipitation, solid plugging, compatibility reversal and formation of emulsions are the main causes of this problem. Formation damage caused by inappropriate drilling, completion, workover and production schemes is a major cost to the oil and gas industry worldwide.

Formation damage makes many producing oil zones to be feasibly uneconomical prospect because of their low productivity because of the changes occurred during production due to improper operating practices. The reservoir rock and resident fluids are essentially in a state of physicochemical and thermodynamic equilibrium. Disruptions in this equilibrium due to changes in pressure, temperature and fluid chemistry around the wellbore region can create barriers to flow and yield lower production rates. This formation damage problem which causes reduction in the overall oil recovery from well and consequently from the reservoir makes it necessary to diagnose and to treat the problem in the early life of the well.
\end{abstract}

The cost of formation damage worldwide is unquestioningly staggering. Reservoirs can undergo different degrees of damage and good producers can still provide sufficient economic return despite near wellbore permeability reduction. Scenarios such as these are even more common than those in which production is ceased on below economic limits. It is often not a question of whether a formation has been damaged, but if the reservoir has been optimally stimulated and is operating at its maximum potential.

The objective of this research is to study and investigate the causes of formation damage in some Western Sirte Basin carbonate reservoirs in Libya. The study has indicated that acid insoluble scales such as barium and calcium sulfate scales are the main salt scales precipitated in the well bore of many producing wells.

The results of this study indicated that inorganic scale precipitation has contributed most to the scaling problems resulted from drilling, completion, workover and stimulation fluids as well as from the produced water during the production phase of the wells. Other major mechanisms such as mud solids plugging, clay swelling, emulsions water blocks, wettability alteration, reduced relative

${ }^{1}$ Professor of Petroleum Engineering and Research and projects Coordinator University of Tripoli Libya. Associate researcher at the University of Hamburg, Harburg, Germany.

${ }^{2}$ Professor of Petroleum Engineering and Research Supervisor at United Arab Emirates University, Al Ain, UAE.

${ }^{3}$ Associate Professor of Petroleum Engineering at the University of Tripoli Libya, Tripoli Libya.. permeability, organic scaling, and bacteria plugging were investigated and outlined in this paper.

Keywords - Sirte basin, Incompatibility, Wettability alteration, Fine movement.

\section{INTRODUCTION}

$\boldsymbol{Q}_{\mathrm{a}}^{\mathrm{O}}$ ORMATION damage assessment and control necessitates a synergistic approach between both the geologists and engineers. Traditionally drilling, completion and stimulation practices have been carried out with minimal detailed geological information. General lithology, bed thickness and averaged petrophysical constraints are the primary geological input variables used for designing drilling and completion programs.

Extensive research shows, however, that detailed microscopic information used to identify the type and distribution of pore filling constituents is necessary in order to properly design drilling, completion and stimulation programs. Thin section petrography, x-ray diffraction and scanning electron microscopy are also effective tools for the evaluation of damage after simulated core flow tests are performed. A generalized approach to completion procedures will invariably cause problems, as mineralogy is not only variable between areas but changes within different units of the same formation $^{1,2}$.

Attendant with these changes in surface and interfacial properties is the potential for intimate mixing of extraneous oil with the formation water or foreign aqueous fluids with the reservoir oil to form either oil or water external emulsions. Emulsion particles, which are larger than pore throat sizes, will block the pores, increase viscosity and thus reduce effective hydrocarbon mobility and impair productivity. ${ }^{3,4}$ Table 1 illustrates the origin, mechanism and type of formation damage problems encountered in many oil or gas producing wells ${ }^{5}$. If stimulation procedures such as acidizing and fracturing, and completion procedures such as perforation density and design optimum oil flow rates, are not optimized with respect to reservoir lithology, further damage to the formation could occur. Matrix acid treatments with $\mathrm{HCl}$ acids could result in release of mineral fines, and precipitation of reactionbyproducts ${ }^{6}$. 


\section{FORMATION DAMAGE IDENTIFICATION METOHS}

The identification of the causes and the origin of the formation damage present in the studied Sirte basin oil fields were carried by:

1. Investigation of mineralogical composition of the reservoir producing formations. This was done by analyzing laboratory results of several core plugs collected from several oil fields in the basin. The core analyses indicated that substantial amounts of smectite and illite clays were present in these formations ${ }^{7}$.

2. Lithology well log analysis also indicated the presence of such clays in most of the producing formations of the studied fields. The clays were interbedded within the matrix structure of the rock. These interbedded clays can be dislodged and migrate upon the reduction of the confining pressure holding them together with the reservoir rock grains. The migration of these fines, as it was stated before, was responsible for some of the formation damage evidenced in these fields ${ }^{8,9}$.

3. The analyses of buildup test results from wells in these fields indicate that different scales such as calcium carbonates, strontium sulfates and magnesium carbonates were found in these reservoirs. The core flooding experiments run purposely for the investigation of the possibility of the formation of inorganic scales in the wellbore region indicated scales such as $\mathrm{SrSO}_{4}, \mathrm{CuSO}_{4}$, $\mathrm{CaCO}_{3}$ and $\mathrm{MgCO}_{3}$ might form in the wellbore if the bottom hole conditions are altered. These scales also were formed due to change of wellbore environment, pressure and flow velocity of the reservoir fluids near the wellbore. The formation of these scales in the wellbore region is also another cause of the formation damage problems encountered in these fields ${ }^{10,11}$.

\section{FIELD ANALYSIS OBSERVATION AND ANALYSIS}

The observation obtained from field reports and field scale laboratory measurements indicated that the scale was found in many parts of the producing system starting from the well head to the bottom of the well. The scale analysis indicated the presence of calcium and strontium sulfate scales in the producing water as well as in the well tubular goods. Several acid treatments were unsuccessful to remove the scale because these sulfate scales are not soluble in acids.

TABl1: Potential Formation Damage Problems During Various Well OPERATIONS

1. DRILLING

MUD SOLIDS AND PARTICLE INVASION

- $\quad$ Pore throat plugging

- $\quad$ Particle movement

\section{MUD FILTRATE INVASION}

- Clay swelling, flocculation dispersion and migration

- Fines movement and plugging of pore throats
- Adverse fluid-fluid interaction resulting in either emulsion/water block or inorganic scaling

2. CASING AND CEMENTING

- Blockage of pore channels by cement or mud solids pushed ahead of the cement.

- Adverse interaction between chemicals (spacers) pumped ahead of cement and reservoir mineral fluids.

- Cement filtrate invasion with resultant scaling, clay slaking, fines migration and silica dissolution.

3. COMPLETION

- Excessive hydrostatic pressure can force both solids and fluids into the formation.

- Incompatibility between circulating fluids and formation with resultant pore plugging.

- Invasion of perforating fluid solids and explosives debris into the formation with resultant pore plugging.

- Wettability alteration from completion fluid additives.

\section{WELL STIMULATION}

- Potential plugging of perforations, formation pores and fractures from solids in the well kill fluid.

- Invasion of circulating fluid filtrate into the formation with resultant adverse interaction.

- Precipitation of hydrofluoric acid reaction by-products during acidizing.

- Precipitation of iron reaction products.

- Potential release of fines and collapse of the formation during acidizing.

\section{PRODUCTION}

- Initiation of fines movement during initial DST by using excessive draw-down pressure.

- Inorganic/organic scaling through abrupt shift in thermodynamic conditions.

- Sand production in unconsolidated formations triggered by water encroachment into production zones.

6. SECONDARY RECOVERY OPERATIONS INJECTION WELLS

- Formation wettability alteration from surface-active contaminants in the injection water.

- Formation plugging by iron corrosion products.

- Inorganic scaling due to incompatibility of injected water and formation water.

- Fines movement due to hydrodynamic conditions of velocity and viscosity during water injection projects.

- Potential emulsion formation during $\mathrm{CO}_{2}$ wag process 
TABLE 2

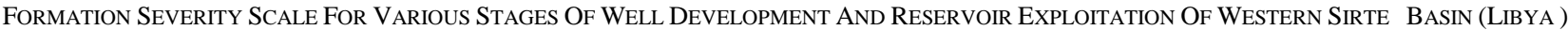

\begin{tabular}{|c|c|c|c|c|}
\hline \multirow[t]{2}{*}{ a) TYPE OF PROBLEM } & \multicolumn{4}{|c|}{ b) WELL DEVELOPMENT } \\
\hline & DRILLING & $\begin{array}{c}\text { COMPLETIO } \\
\mathbf{N}\end{array}$ & $\begin{array}{c}\text { WORKOVE } \\
\text { R }\end{array}$ & $\begin{array}{c}\text { STIMULATIO } \\
\mathbf{N}\end{array}$ \\
\hline MUD SOLIDS PLUGGING & ***** & ** & **** & - \\
\hline FINES MIGRATION & $* * *$ & $* * * *$ & $* * *$ & $* * * *$ \\
\hline CLAY SWELLING & ***** & $* *$ & $* * *$ & - \\
\hline EMULSION/WATER BLOCK & $* * *$ & $* * * *$ & $* *$ & $* * * *$ \\
\hline WETTABILITY ALTERATION & ** & **** & **** & ***** \\
\hline REDUCED RELATIVE PERMEABILITY & $* * *$ & $* * *$ & $* * * *$ & $* * *$ \\
\hline ORGANIC SCALING & $*$ & $*$ & $* * *$ & $* * * *$ \\
\hline INJECTED PARTICULATE PLUGGING & - & $* * * *$ & $* * *$ & $* * *$ \\
\hline INORGANIC SCALING & $* *$ & $* * *$ & $* * * *$ & $*$ \\
\hline BACTERIA PLUGGING & $* *$ & ** & ** & - \\
\hline
\end{tabular}

Number of*`s indicates the severity of the formation damage type

\section{CONCLUSION}

1. Inorganic scales were found to the major cause formation pore plugging in the well bore region. The plugging is caused by the improper production practice employed in producing these wells.

2. Recent field and laboratory advances for assessment and control of formation damage problems have been presented in this paper in table 1 .

3. The severity of the different formation damage problems encountered in the western Sirte basin oil fields during various operations is summarized in Table 2. It is apparent from this table that the most dominant problem is inorganic scale precipitation.

4. It is recommend that extensive research efforts directed at finding effective chemical control for scale precipitation and fines migration problems are highly desirable.

5. In this paper, guidelines for the identification of the causes and origin of formation damage are presented. It is recommended that the results of this study should be used as gudelines for planning future drilling, workover and production operations in theses fields.

\section{REFERENCES}

[1] Hower, W. F.: "Influence of Clays on the Production of Hydrocarbons", SPE 4785, February 1974.

[2] Morizot, A. P., and Neville, A.,: "A Novel Approach for Monitoring of $\mathrm{CaCO}_{3}$ and $\mathrm{BaSO}_{4}$ Scale Formation", Paper SPE 60189 presented at the $2^{\text {nd }}$ SPE International Symposium on Oilfield Scale, Aberdeen, UK, 2627 January 2000. http://dx.doi.org/10.2118/60189-ms

[3] Allen, T. O. and Roberts, A. P.: "Production Operations Well Completions, Workover and Stimulation", Oil and Gas Consultants, Inc., Vols. 1 and 2 (1982).

[4] Krueger, R. F.: "An Overview of Formation Damage and Well Productivity in Oilfield Operations", JPT, February 1988".

[5] Oddo, J. E., and Tomson, M.B.: "A Discussion of Calcium Carbonate Scaling Problems and Solutions with Respect to Produced Brines", Paper SPE 19763 presented at the 1989 SPE Annual Technical Conference and Exhibition, San Antonio, TX, Oct. 8-11. http://dx.doi.org/10.2118/19763-MS

[6] Ali, M. A., and Islam, M.R.: "The Effect of Asphaltene Precipitation on Carbonate-Rock Permeability: An Experimental and Numerical Approach", SPEPF (August 1998) 115.
[7] Leontaritis, K. J., Amaefule, J. O. and Chariles R.E. (1994) "A Systematic Approach for the Prevention and Treatment of Formation Damage Caused by Asphaltene Deposition", SPE Prod. Fac., Aug. 1994, 157-164. http://dx.doi.org/10.2118/23810-PA

[8] Minssieux, L., Nabzar, L., chauveteau, G., Longeron, D., and Bensalem, R.: "Permeability Damage Due to Asphaltene Deposition", Revue de l'Institut Français du Pétrole (1998) 53, 313. http://dx.doi.org/10.2516/ogst:1998027

[9] Amaefulc, J.O., Ajufo, A., Peterson, E., Durst, K.: "Understanding Formation Damage Process: An Essential Ingredient for Improved Measurement and Interpretation of Relative Permeability Data", SPE 16232, March (1987).

[10] Argillier, J.F., SPE, Audibert, A., SPE, Longeron, D., Inst. Français du Pétrole," Performance Evaluation and Formation Damage Potential of New Water Based Drilling Formulation" SPE Drilling and Completion, 14 (4), December 1999. http://dx.doi.org/10.2118/59484-PA

[11] Longeron, D. Inst. Du Pétrole, France, Alfenore, N. Salehi and Saintpere S. "Experimental Approach to Characterize Drilling Mud Invasion, Formatin Damage and Cleanup Efficiency in Horizontal Wells with Openhole Completions" SPE international formation damage symposium, Lafayette, USA, 23-24 Feb. 2000. 